\title{
Japan backs the production of vectors for gene therapy
}

Tokyo. Seven Japanese pharmaceutical companies, backed by a semi-governmental organization of the Ministry of Health and Welfare, have set up a company to develop new vectors for gene therapy.

The move is the latest Japanese attempt to catch up with advanced Western nations - in particular the United States - in the application of gene therapy. But many fundamental problems in the structure of Japan's research system are likely to impede the achievement of that goal.

It also coincides with the news that the US National Institutes of Health (NIH) have been issued a broad patent covering all $e x$ vivo applications of gene therapy, based on the work of French Anderson and his colleagues. This technology has been exclusively licensed to Genetic Therapy Inc. (GTI) in Gaithersburg, Maryland (see page 393).

The new company, known as DNAVEC Research Inc., is being set up jointly by Hisamitsu, Kyowa Kakko Kogyo, Sankyo, Shionogi, Yamanouchi, Tanabe and Sumitomo Pharmaceuticals. It will use laboratory space rented from a new research institute set up by Hisamitsu that opened last month in Tsukuba science city, and will be headed by a researcher from Kyowa Kakko.

Of the company’s initial capital of $¥ 482$ million ( $\$ 5.4$ million), $¥ 300$ million was provided by the Ministry of Health and Welfare's Investigative Organization for Side Effects Relief and Research Promotion. This semi-governmental organization, originally set up to compensate victims of side effects from drugs, now invests large amounts of money in research. Over the next seven years, $¥ 4$ billion ( $\$ 45$ million) is expected to be invested in DNAVEC, much of it from the semi-governmental organiza- tion and the rest from the drug companies.

The first clinical application of gene therapy in Japan, involving the treatment of a four-year-old boy suffering from adenosine deaminase (ADA) deficiency, was approved last month by two government committees and is expected to be carried out shortly at Hokkaido University School of Medicine.

But the treatment is based on a technique developed by Anderson and his colleague Michael Blaese at the NIH. The Hokkaido University group has been almost entirely dependent on US data to prove the efficacy and safety of the technique, and the retroviral vector for the treatment will have to be imported from GTI .

It is to overcome these deficiencies that the ministry and industry have established DNAVEC. In contrast to most Western countries, where a company such as GTI would be set up by venture capitalists, in Japan it has required government backing. One reason is that government regulations make it extremely difficult to establish venture businesses. The Ministry of International Trade and Industry is trying to persuade the Ministry of Finance to ease the regulations. But little progress has yet been made.

Another difference is that in the West, such venture businesses are often led by prominent researchers; Anderson, for example, is chairman of GTI's science advisory board. In Japan, researchers in universities and government institutes are government employees, and thus not allowed to set up such venture businesses. Some research leaders in the pharmaceutical industry are therefore sceptical whether DNAVEC will be able to come up with innovative vectors to break away from dependence on Western technology.

David Swinbanks

\section{Supercomputer plans fail to reach lift-off}

Paris. "Force of personality isn't enough to overcome market reality". This was the response of some analysts this week to news of difficulties facing two ambitious supercomputer companies.

In the United States, Cray Computer Corporation, headed by Seymour Cray, the founder of the supercomputing industry, filed for protection from creditors under Chapter 11 legislation. In France, Stern Computing Systems, headed by Jacques Stern, a former chairman of the French state-owned computer company, Bull, announced it had gone into receivership.

Seymour Cray created Cray Computer in 1989, after leaving Cray Research, the company he set up in 1972, to build vector supercomputers based on gallium-

arsenide chips. Despite highly-rated technology, the Cray 4 machine hit production problems, and investors lost patience.

SCS, which last year promised to market a "breakthrough" supercomputer (see Nature 371, 91; 1994) met a similar fate in pursuing purpose-built systems using reduced instruction set computing (RISC). "We had the technology, but we couldn't get the financing to bring the prototype to production", says Stern.

SCS is to be bought by Compagnie des Signaux - which makes computers for transport systems - and Défense Conseil International. The company has laid off 100 of its 150 staff, including Stern. Seymour Cray may yet obtain the funds to relaunch his company. Declan Butler
NSF under fire for excluding white student from camp

Washington. A white high-school student is suing the US National Science Foundation (NSF) for racial discrimination after she was refused entry to an NSF-sponsored summer camp designed to stimulate the interest of teenagers in science.

The summer camp was organized by Texas A\&M University, and funded by the Texan state government and a grant from the NSF's Summer Science Camps (SSC) programme. The science agency's information on the SSC programme specifies that participants "must be underrepresented minority students". Lawyers for the unnamed teenager say that this requirement breaches the 1964 Civil Rights Act.

Their 14-year-old client was attending a middle school in Corpus Christi, Texas, at which 97 per cent of the students were from minority groups, when she applied to join the programme. Her lawyers say that she was responding to publicity produced by the university's outreach programme, which made no mention of race. When she attended an interview, they say, she was told she was ineligible.

The lawsuit is being pursued by the Center for Individual Rights, a conservative legal group based in Washington. The NSF has 60 days to respond; according to a spokesman, the agency is likely to argue that it is required by law to take action to attract more minority students into science.

But some affirmative action experts expressed surprise that the NSF programme stipulated so explicitly that only minority students could participate. "Most institutions have not been so restrictive, because we know that legally we can't do that," says James Wyche, associate provost of Brown University, Rhode Island.

According to Wyche, such programmes are usually designed to target minority students, but not to exclude others. Organizers can then argue that the programmes are open to all socially disadvantaged groups, and therefore they do not breach the Civil Rights Act.

The racial discrimination suit names Neal Lane, the director of NSF, Frank Rhodes, the chairman of the National Science Board, Luther Williams, head of the education and human resources directorate at the agency, and various other officials at both NSF and Texas A\&M.

The case comes at a time when political pressure is building up against affirmative action programmes in the United States (see Nature 373, 645; 1995). But even if it succeeds, its direct impact may be limited, as other affirmative action programmes are designed to avoid the explicit exclusion of white students.

Colin Macilwain 